\title{
ShRNA-MEDIATED KNOCKDOWN OF PITUITARY TUMOR TRANSFORMING GENE 1 (PTTG1): OPTIMIZATION OF THE EFFECT ON EARLY OSTEOBLAST DIFFERENTIATION
}

\author{
Kh. V. Malysheva ${ }^{1,2,3}$, O. K. Pavlenko, R. S. Stoika ${ }^{1,4}$, O. G. Korchynskyi ${ }^{1,3}$ \\ olexkor@hotmail.com
}

${ }^{1}$ Institute of Cell Biology NAS of Ukraine,

14/16 Drahomanov str., Lviv 79005, Ukraine

${ }^{2}$ Insitute of Animal Biology NAAS,

38 V. Stus str., Lviv 79034, Ukraine

${ }^{3}$ Centre for Innovative Research in Medical and Natural Sciences,

Rzeszow University and Medical Faculty,

1A Warshawna str., Rzeszow 35-310, Poland

${ }^{4}$ Ivan Franko National University of Lviv,

4 Grushevsky str., Lviv 79005, Ukraine

Rheumatoid arthritis (RA) is a chronic inflammatory disorder characterized by massive joint destruction. Bone erosion belongs to the most painful consequences of $R A$ that are tightly associated with disease severity and poor functional outcome. It is well known that bone morphogenetic protein (BMP) and Wnt regulatory pathways are involved in cartilage and bone formation and maintenance. We hypothesize that pituitary tumor transforming gene 1 (PTTG1)/(PTTG)-binding factor 1 (PBF1) axis serves as a new negative regulator of bone homeostasis with involvement into RA progression and pathogenesis.

The aim of this study was to investigate the effect of small hairpin (sh) RNA-mediated knockdown of PTTG1 mRNA expression on the early stages of BMP-induced osteoblast differentiation. Analysis of the experiment results was performed by spectrophotometric measurement of alkaline phosphatase activity, which is widely used as a marker of early osteogenesis.

We have found that shRNA-mediated knockdown of PTTG1 mRNA expression potentiated early stages of osteoblast differentiaion in stable multi-clonal cultures of C2C12 and KS483 cell lines. The most pronounced effect was found at the action of anti-PTTG1_shRNA-1 whose stable expression stimulated osteoblast differentiation of C2C12 and KS483 cells (2.1 fold and 2.7 fold, respectively), whereas anti-PTTG1 shRNA-3 stable expression did not show any significant effect on the osteoblast differentiation of these cells. Thus, we demonstrated that PTTG1 is an important repressor of early stages of osteogenesis and can serve as an inhibitor of bone remodelling, in particular, during $R A$ progression.

Keywords: PITUITARY TUMOR TRANSFORMING GENE 1, SMALL HAIRPIN RNAs, OSTEOBLAST DIFFERENTIATION, MURINE MESENCHYMAL STEM CELLS, BONE MORPHOGENETIC PROTEINS, RHEUMATOID ARTHRITIS

\section{НОКДАУН ГЕНУ ПУХЛИННОЇ ТРАНСФОРМАЦЇ̈ КЛІТИН ГІПОФІЗУ 1 (РТТG1), ОПОСЕРЕДКОВАНИЙ МШРНК: ОПТИМІЗАЦІЯ ЕФЕКТУ НА РАННІЙ СТАДІЇ ОСТЕОБЛАСТНОЇ ДИФЕРЕНЦАЦІЇ}

\author{
Х. В. Малишева $a^{1,2,3}$, О. К. Павленко ${ }^{3}$, Р. С. Стойка ${ }^{1,4}$, О. Г. Корчинський ${ }^{1,4}$ \\ olexkor@hotmail.com
}

${ }^{1}$ Інститут біології клітини НАН України, вул. Драгоманова, 14/16, м. Львів, 79005, Україна

${ }^{2}$ Інститут біології тварин НААН, вул. В. Стуса, 38, м. Львів, 79034, Україна

${ }^{3}$ Центр інноваційних досліджень в галузі медицини та природничих наук і Медичний факультет, Жешувський університет, вул. Варшавна, 1А, м. Жешув, 35-310, Польща 
4Львівський національний університет імені Івана Франка, вул. Грушевского, 4, м. Львів, 79005, Україна

Ревматоїдний артрит (РА) - ие хронічне запальне захворювання, яке характеризується масивним руйнуванням тканин суглобів. Ерозія кісткової тканини належить до найбільш болючих наслідків РА й асоціюється з важккістю захворювання і несприятливим функціональним результатом. Відомо, що морфогенетичні протеїни кістки (МПК) і сигнальний ланџюг Wnt належать до ключових регуляторних иляхів, які індукують і підтримують формування хрящової та кісткової тканин. Ми припускаємо, щуо ген пухлинної трансформації клітин гіпофізу 1 (PTTG1) та PTTG1-зв'язувальний протеїн 1 (PBF1) є важсливою системою, яка виконує функцію нового негативного регулятора гомеостазу кісткової тканини, i, ймовірно, задіяна у патогенезі $Р$ А.

Метою ивого дослідження було вивчити вплив нокдауну експресії мРНК гену PTTG1, опосередкованого малими шпильковими (мш) РНК, на ранні стадії МПК-індукованої остеобластної диференціації. Аналіз результатів експериментів проводили методом спектрофотометрії через вимірювання активності лужної фосфатази як маркера ранніх стадій остеогенезу.

Показано, що блокування експресії мРНК гену PTTG1, опосередковане мшРНК, посилювало ранні стадії остеобластної диференціачії у стабільних мультиклональних культурах клітин ліній C2C12 і КS483. Найбільш виражений ефект виявлено для анти-PTTG1_мшРНК-1, експресія якої значно підсилювала остеобластну диференціацію С2C12 і КS483 клітин (відповідно, у 2,1 і 2,7 разу), тоді як стабільна експресія анти-PTTG1_миРНК-3 не виявила істотного впливу на остеобластну диференціацію иих клітин. Таким чином, показано, щзо PTTG1 є важливим репрессором ранніх стадій остеогенезу $i$, можливо, задіяний у руйнуванні кісткової тканини, зокрема під час прогресування $P A$.

Ключові слова: ГЕН ПУХЛИННОЇ ТРАНСФОРМАЦІЇ КЛІТИН ГІПОФІЗУ 1, МАЛІ ШПИЛЬКОВІ РНК, ОСТЕОБЛАСТНА ДИФЕРЕНЦІАЦІЯ, МЕЗЕНХІМНІ СТОВБУРОВІ КЛІТИНИ МИШІ, МОРФОГЕНЕТИЧНІ ПРОТЕЇНИ КІСТКИ, РЕВМАТОЇДНИЙ АРТРИТ

\title{
НОКДАУН ГЕНА ОПУХОЛЕВОЙ ТРАНСФОРМАЦИИ КЛЕТОК ГИПОФИЗА 1 (РТТG1), ОПОСРЕДОВАННЫЙ КШРНК: ОПТИМИЗАЦИЯ ЭФФЕКТА НА РАННЕЙ СТАДИИ ОСТЕОБЛАСТНОЙ ДИФФЕРЕНЦИАЦИИ
}

\author{
Х. В. Мальишева ${ }^{1,2,3}$, О. К. Павленко ${ }^{3}$, Р. С. Стойка ${ }^{1,4}$, О. Г. Корчинский ${ }^{1,4}$ \\ olexkor@hotmail.com
}

\begin{abstract}
${ }^{1}$ Институт биологии клетки НАН Украины, ул. Драгоманова, 14/16, г. Львов, 79005, Украина

${ }^{2}$ Институт биологии животных НААН, ул. В. Стуса, 38, г. Львов, 79034, Украина
\end{abstract}

${ }^{3}$ Центр инновационных исследований в области медицины и естественных наук и Медицинский факультет, Жешувский университет, ул. Варшавная, 1А, г. Жешув, 35-310, Польша ${ }^{4}$ Львовский национальный университет имени Ивана Франко, ул. Грушевского, 4, г. Львов, 79005, Украина

Ревматоидный артрит (РА) - хроническое воспалительное заболевание, характеризующееся массивным разрушением тканей суставов. Эрозия костной ткани относится к наиболее болезненным последствиям РА и ассочиируется с тяжестью заболевания и неблагоприятным функииональным результатом. Известно, что морфогенетические протеины кости (МПК) и сигнальная цепь Wnt принадлежат к ключевым регуляторным путям, которые индуцируют и поддержсивают формирование хрящевой и костной тканей. Мы предполагаем, что ген опухолевой трансформации клеток гипофиза 1 (PTTG1) и PTTG1связывающий протеин 1 (PBF1) является важной системой, которая выполняет функиию нового негативного регулятора гомеостаза костной ткани, и, вероятно, задействована в патогенезе РА.

Целью данного исследования было изучение влияния нокдауна экспрессии мPНК гена PTTG1, опосредованного короткими шпильковыми (кш) РНК, на ранние стадии остеобластнои дифференциации, индуцированной МПК. Анализ результатов эксперимента проводился спектрофотометрическим измерением активности щелочной фосфатазы, которая широко используется в качестве маркера раннего остеогенеза. 
Установлено, что блокирование экспрессии мРНК гена PTTG1, опосредованное киРНК, усиливало ранние стадии остеогенеза в стабильных мультиклональних культурах клеток линий C2C12 и KS483. Наиболее выраженный эффект показан для анти-PTTG1_кшPHК-1, экспрессия которой значительно усиливала остеобластну дифференциацию С2C12 и КS483 клеток (в 2,1 и 2,7 раза соответственно), тогда как стабильная экспрессия анти-PTTG1_кшРНК-3 не сопровождалась существенным влиянием на остеобластную дифференциацию этих клеток. Таким образом, установлено, что PTTG1 является важным репрессором ранних стадий остеогенеза и, возможно, задействован в разрушении костной ткани, в частности во время прогрессирования РА.

КлючевЫе сЛова: ГЕН ОПУХОЛЕВОЙ ТРАНСФОРМАЦИИ КЛЕТОК ГИПОФИЗА 1, КОРОТКИЕ ШПИЛЬКОВЫЕ РНК, ОСТЕОБЛАСТНАЯ ДИФФЕРЕНЦИАЦИЯ, МЕЗЕНХИМАЛЬНЫЕ СТВОЛОВЫЕ КЛЕТКИ МЫШИ, МОРФОГЕНЕТИЧЕСКИЕ ПРОТЕИНЫ КОСТИ, РЕВМАТОИДНЫЙ АРТРИТ

Rheumatoid arthritis (RA) is a chronic, systemic autoimmune inflammatory disorder that may affect many tissues and organs, but primarily attacks the synovium of joints. The process induces synovitis, synovial hyperplasia with neovascularization and overproduction of the synovial fluid, which causes joint swelling, stiffness, and pain. The final consequences are the destruction of articular cartilage and the bones erosions within the joints $[12,38]$. The disease has a significant medical and social impact, since the absence of effective treatment leads to rapid development of disability and reduced quality of patients' life [5, 9, 27]. Although the RA has been the subject of numerous investigations, exact molecular mechanisms that trigger a disease and exacerbate its progression stay poorly understood [30]. Strikingly, several signaling pathways are strongly dis-regulated in fibroblast-like synoviocytes, monocytes, neutrophils, endothelial and other cells in joints of the RA patients [5, 27, 39]. It was shown that bone morphogenetic protein (BMP) and Wnt signaling pathway are key players that induce and support cartilage and bone formation and maintenance $[2,25$, $26,31]$. The activation of Wnt pathway participates in the formation of a proper balance between bone and cartilage formation and remodeling. However, in patients with RA and other skeletal disorders this balance is disturbed $[5,13,25,35]$.

Different studies of human rheumatic and orthopedic diseases and specific mouse models with both activating and null mutations of proteins required for canonical Wnt signaling suggest a crucial role for this signaling pathway in the regulation of bone formation, maintenance, reparation and remodeling by regulating osteoblast and osteoclast proliferation and differentiation $[3$,
$10,14,15]$. Osteoblast differentiation is supported predominantly by BMPs (the members of the transforming growth factor $\beta$ (TGF- $\beta$ ) superfamily) and by Wnt proteins. Although commitment of mesenchymal precursors to the osteo- and chondrogenic lineages requires a precise coordination of Wnt and BMP signals, the canonical Wnt pathway subsequently acts as master regulator of the osteogenesis $[1,23]$.

Wnt/ $\beta$-catenin signaling regulates osteogenesis through multiple mechanisms. Wnts repress alternative mesenchymal differentiation pathways such as adipocyte and chondrocyte differentiation and promote osteoblast differentiation, proliferation, and mineralization activity, while blocking osteoblast apoptosis. By increasing the ratio of osteoprotegerin (OPG)/receptor activator of nuclear factor kappa-B ligand (RANKL), $\beta$-catenin represses osteoclastogenesis $[16,21]$. In a physiological state, cortical bone formation and resorption next to joints are in balance but inflammatory diseases such as RA lead to an imbalance between these processes. Bone formation is hampered by tumor necrosis factor (TNF)mediated expression of inhibitors which suppress Wnt signals, whereas bone resorption is enhanced by the expression of RANKL [6] — a key factor for osteoclast differentiation and activation.

In terms of commitment and differentiation, there is crosstalk between the Wnt and BMP pathways. Wnt directly controls the expression of a series of genes playing crucial roles in osteoblast biology [36].

Pituitary tumor-transforming gene (PTTG) is a proto-oncogene that was first isolated from rat pituitary tumor GH4 cells [33]. Subsequent studies demonstrated that its protein product Se- 
curin mediates sister chromatid separation during mitosis [46]. The mechanisms of PTTG action include protein-protein interactions, transcriptional activity, and paracrine/autocrine regulation. During mitosis and following chromosome alignment, PTTG is degraded in the proteasomes at metaphase to anaphase transition through the anaphase-promoting complex/cyclosome, releasing inhibition of separase, which in turn mediates the proteolysis of the cohesins ring that holds sister chromatids together [28].

The PTTG family includes PTTG1, PTTG2, and PTTG3 [37, 41]. Human PTTG1 gene is located on chromosome 5 and encodes Securin - a protein consisting of 202 amino acids $(22 \mathrm{kDa})$ [41]. In human, PTTG1 exhibits 91 and $89 \%$ amino acid sequence homology with PTTG2 and PTTG3, respectively [33]. PTTG1 is the most abundant and widely studied form of the substance [37]. Both PTTG1 gene inactivation and its excessive expression lead to the appearance of aneuploid cells [28].

Over-expression of PTTG1 gene was reported to occur in several neoplasms, including pituitary tumors, as well as carcinomas of lung, breast, esophagus, colon, rectum, and ovary. PTTG1 is implicated in several normal cellular processes, including DNA damage repair, apoptosis, and angiogenesis. It also interacts with a number of factors both in vivo and in vitro [28,37]. PTTG1 also possesses trans-activating action and induces upregulation of several other genes [37].

Mice lacking PTTG1 gene show testicular and splenic hypoplasia, thymic hyperplasia, thrombocytopenia, aberrant cell cycle progression, and premature centromere division [43, 44].

Subcellular PTTG1 localization, particularly the significance of cytoplasmic versus nuclear expression, remains controversial. Nuclear PTTG1 functions as a Securin, inhibitor of premature sister chromatid separation, as well as a potential transcriptional activator, whereas the role of cytoplasmic PTTG1 remain unclear. While differential PTTG1 localization may be due to the variations in cell lines and tumor types examined, cell cycledependent expression of PTTG1 gene may also account for the reported differences. Translocation of PTTG1 from cytoplasm to nucleus might be mediated by the PTTG-binding factor (PBF) which contains a nuclear localization signal $[4,37]$.
Another mechanism proposed to be involved in PTTG1 translocation is based on functioning of the mitogen-activated protein kinase (MAPK) pathway [32, 37, 45].

It was shown that PBF1 gene expression was reduced in long standing RA comparably to early stages of RA [24]. Simultaneously, PBF1 is a target gene for RUNX2 - osteoblastspecific transcription factor [40]. Therefore, one can hypothesize that PTTG1/PBF1 axis represents a novel key system in regulating homeostasis of joint tissues with involvement into RA progression and pathogenesis of other related diseases.

According to our preliminary data, PTTG1 gene overexpression leads to a potent inhibition of Wnt signaling pathway in target cells (unpublished data). Such result allows suggesting that PTTG1/PBF1 system can serve as a new negative regulator of bone and potentially cartilage homeostasis. In present study, we explored the effect of stable shRNA-mediated knockdown of PTTG1 mRNA expression on the early stages of BMP-induced osteoblast differentiation.

\section{Materials and methods}

Cell culture. Our studies were performed with immortalized mouse mesenchymal stem cells of $\mathrm{C} 2 \mathrm{C} 12$ and $\mathrm{KS} 483$ lines cultured in the Dulbecco's modified Eagle's medium (DMEM; Sigma-Aldrich, Germany) containing $10 \%$ fetal bovine serum (FBS; Biowest, France). The cells were grown in a $5 \% \mathrm{CO}_{2}$-containing atmosphere at $37{ }^{\circ} \mathrm{C}$ and $100 \%$ humidity. Culture medium was changed every 2-3 days. Before sub-cultivation, cells were washed with the phosphate-buffered saline (PBS) that contained $137 \mathrm{mM} \mathrm{NaCl}$, $2.7 \mathrm{mM} \mathrm{KCl}, 4.3 \mathrm{mM} \mathrm{Na}_{2} \mathrm{HPO}_{4}$ and $1.4 \mathrm{mM}$ $\mathrm{KH}_{2} \mathrm{PO}_{4}$ with $\mathrm{pH}$ 7.4.

Before seeding, cell viability was monitored using the Trypan blue staining solution $(0.1 \%)$, and cell number was counted in the hematocytometer chamber.

Short (small) hairpin RNA (shRNA). The set of validated shRNA lentiviral constructs that specifically target the expression of mouse version of PTTG1 mRNA and scrambled shRNA was purchased as a part of MISSION library from Sigma-Aldrich (USA). 
Stable infection. C2C12 and KS483 cells were plated in a complete growth medium overnight. Lentiviral particles were added at the multiplicity of infection $(\mathrm{MOI})=5$ or $=10$ in the presence of diethylaminoethyl (DEAE)-dextran, and cells were incubated for 24 hours. Then, equal amount of fresh culture medium with no lentivirus was added, and the cells were incubated for additional 24 hours. Two days later, efficiently transduced cells were selected by adding 3-4 $\mu \mathrm{g} / \mathrm{ml}$ of puromycin (PanreacAppliChem, Spain) for next seven days. Obtained puromycin-resistant multi-clonal cultures of indicated cell lines were maintained on $1 \mu \mathrm{g} / \mathrm{ml}$ of puromycin and used for studies. Two weeks (for KS483) or three weeks (for $\mathrm{C} 2 \mathrm{C} 12$ cells) after transduction, these cells were tested for the expression of the lentiviral $\mathrm{p} 24 / \mathrm{Gag}$ capsid protein using ELISA ( $R \& D$ Systems, USA) and no Gag p24 was detected. An efficacy of shRNA knockdown was confirmed using the Real-Time RT-PCR amplification (data not shown).

\section{Induction of osteoblast differentiation.}

C2C12 and KS483 cell lines were induced to differentiate into osteoblasts by different BMPs, including BMP2 and BMP7 [17]. These cells were split at a density of $1.5 \times 10^{4}$ cells per $\mathrm{cm}^{2}$ in 24 well plates. Next day, cells were transduced with a combination of adenoviral constructs encoding recombinant $\mathrm{BMP} 2$ and $\mathrm{BMP} 7$ at the MOI even to 500 for each one construct [18] to induce a production of BMP $2 / 7$ heterodimers along with appropriate homodimers. During osteogenesis assay, $\mathrm{C} 2 \mathrm{C} 12$ and KS483 cells were cultured for 4 days in a differentiation-supporting medium supplemented with $50 \mu \mathrm{g} / \mathrm{ml}$ ascorbic acid.

Alkaline phosphatase assay. The alkaline phosphatase activity (ALP, EC 3.1.3.1) produced by $\mathrm{C} 2 \mathrm{C} 12$ and $\mathrm{KS} 483$ cells was analyzed spectrophotometrically using a $\pi$-nitrophenylphosphate $(\pi$-NPP) as a substrate [42]. Four days after the induction of osteogenesis, the supernatants were withdrawn and cells were washed twice with PBS. The cells were lysed in ALP lysis buffer that contained $10 \mathrm{mM}$ glycine, $100 \mu \mathrm{M} \mathrm{MgCl}, 10 \mu \mathrm{M}$ $\mathrm{ZnCl}_{2}$ and $0.1 \%$ Triton X100. Then, $10 \mu \mathrm{l}$ of cell lysate and $90 \mu \mathrm{l}$ of ALP assay buffer $(100 \mathrm{mM}$ glycine, $1 \mathrm{mM} \mathrm{MgCl}{ }_{2}, 100 \mu \mathrm{M} \mathrm{ZnCl}_{2}$ ) supplemented with $6 \mathrm{mM} \pi \mathrm{NPP}$ (PierceThermo Fisher Scientific, USA) [42], were mixed gently and incubated at room temperature. Following the reaction with alkaline phosphatase, a yellow reaction product forms may be read at $405 \mathrm{~nm}$. The optical density was measured $\left(\mathrm{OD}_{405}\right)$ in 96 well plate reader (BioTek, USA). The color intensity is directly proportional to the amount of ALP.

Statistical analysis. All experiments were repeated twice, using three parallel wells $(n=3)$ in each variant. Results of spectrophotometric measurements of ALP activity were expressed as a mean \pm standard deviation $(\mathrm{M} \pm \mathrm{SD})$. Data were analyzed using GraphPad Prism 6 program. Statistical differences between experimental variants were assessed by Student's $t$-test. Appropriate $P$ values were shown in graphs to demonstrate the significance of the results. Only differences with $\mathrm{P}$-values lower than 0.05 were considered as significant.

\section{Results and discussion}

In this study, the effect of stable shRNAmediated knockdown of PTTG1 mRNA expression on early stages of BMP-induced osteoblast differentiation was explored. In our experiments, we used mouse mesenchymal stem cells of $\mathrm{C} 2 \mathrm{C} 12$ and KS483 lines that can be induced to differentiate into osteoblasts by different BMPs, including BMP2 and BMP7 [17].

Nowadays, the use of RNA interference (RNAi) has emerged as a powerful tool for the study of gene function in mammalian cells. The mechanism of RNAi is based on the sequencespecific degradation of host mRNA through the cytoplasmic delivery of double-stranded RNA (dsRNA) identical to the target sequence. Whilst there are several options for synthetic and expressed RNAi: the most commonly-used form of synthetic RNAi is siRNA, and of expressed RNAi is shRNA [7, 29].

ShRNA-expressing constructs are frequently applied as a convenient substitution for transient transfection with small interfering RNA (siRNA) specifically targeting gene expression due to allowing to avoid initial side effects of transfection required for siRNA delivery to the cells. Transient overexpression of shRNA targeting gene mRNA expression, similarly to many other siRNA and shRNA, always induces some off-target inter- 
feron response (data not shown). Therefore, we generated lentivirally transduced multi-clonal cultures of $\mathrm{C} 2 \mathrm{C} 12$ and $\mathrm{KS} 483$ cells with stable expression of shRNAs that specifically target the expression of PTTG1 mRNA (anti-PTTG1_shRNA-1, antiPTTG1_shRNA-2 and anti-PTTG1_shRNA-3) and scrambled shRNA that does not have target gene was used as a control. These cell cultures were obtained in Leiden University (The Netherlands) through cooperation carried out by Dr. O. Korchynskyi. Cells of C2C12 and KS483 lines were transduced with lentiviral constructs encoding indicated shRNAs and scrambled shRNA. Transduced cells were selected by adding puromycin. As a result of next ELISA testing for the presence of the lentiviral Gag p24 capsid protein, no Gag p24 was detected.

According to EU rules for Genetically modified organisms handling, the obtained Gag p24-negative puromycin-resistant multi-clonal cultures of $\mathrm{C} 2 \mathrm{C} 12$ cells were allowed to culture at the Biosafety Level I lab, brought to Ukraine, and the used in further experiments. An efficacy of shRNA knockdown was confirmed with a Real-Time RTPCR amplification and varied from 6.5 to 8 times for most efficient variants (data not shown).

In appropriate variants of the experiments, C2C12 and KS483 cells were treated with a mixture of recombinant BMP2 and BMP7 adenoviruses to induce their osteoblast differentiation. BMPs have been reported to induce gene expression of various extracellular matrix proteins in mesenchymal cells and osteoblasts. In particular, the BMP-induced gene expression of ALP is widely applied as a marker of early stages of BMP-induced osteoblast differentiation $[8,11$, $17,19,20]$. Thus, like other investigators, we successfully used it in our studies. The results of spectrophotometric measurement of ALP activity are presented in fig. 1 and fig. 2.

Efficient shRNA constructs intensified early stages of the osteoblast differentiation in stable multi-clonal cultures of $\mathrm{C} 2 \mathrm{C} 12$ and KS483 cells as compared with control cells that normally expressed PTTG1 gene.

As shown on fig. 1 and fig. 2, the most pronounced effect was found for anti-PTTG1 shRNA-1 which expression stimulated osteoblast differentiation of both $\mathrm{C} 2 \mathrm{C} 12$ cells ( 2.1 fold) and KS483 cells
(2.7 fold) when compared with scrambled shRNA $(1.175 \pm 0.025, \mathrm{n}=3$ and $0.108 \pm 0.010, \mathrm{n}=3$, respectively). The anti-PTTG1_shRNA-3 expression did not show a significant influence on the osteoblast differentiation of model cells.

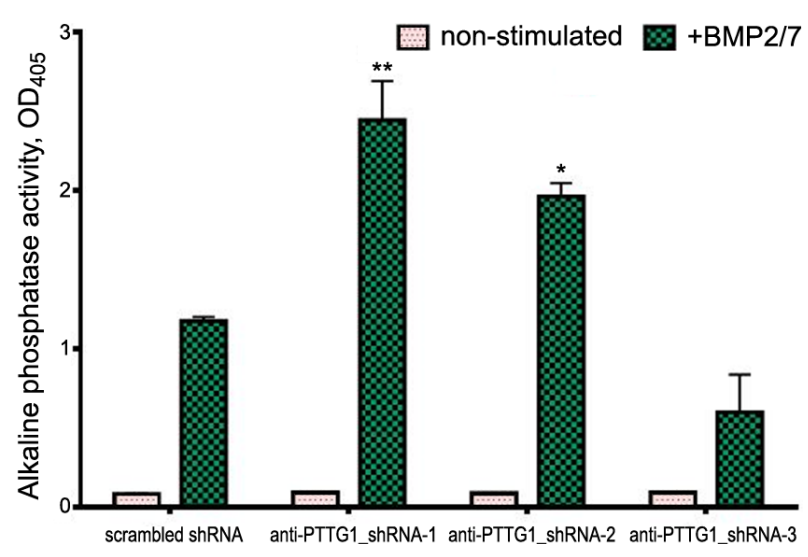

Fig. 1. Alkaline phosphatase activity in the lysates of $\mathrm{C} 2 \mathrm{C} 12$ cells with stable expression of shRNAs that specifically target the expression of PTTG1 mRNA (anti-PTTG1 shRNA-1, anti-PTTG1 shRNA-2 and anti-PTTG1_shRNA-3) and scramb̄led shRNA that was used as a control

Stable lentivirally transduced multi-clonal cultures of C2C12 cells were split into 24-well plates and treated with a mixture of recombinant BMP2 and BMP7 adenoviruses to induce their osteoblast differentiation. Alkaline phosphatase activity was analyzed in cell lysates spectrophotometrically. Optical density at $405 \mathrm{~nm}$ is shown. Statistical differences are indicated $(*-P<0.05, * *-P<0.01)$.

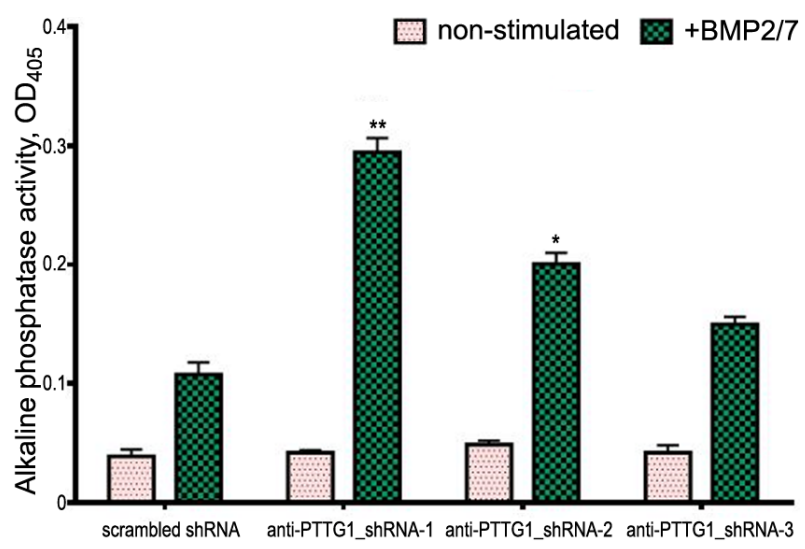

Fig. 2. Alkaline phosphatase activity in the lysates of KS483 cells with stable expression of shRNAs that specifically target the expression of PTTG1 mRNA (antiPTTG1 shRNA-1, anti-PTTG1 shRNA-2 and anti-PTTG1_shRNA-3) and scrambled shRNA that was used as a control

Stable lentivirally transduced multi-clonal cultures of KS483 cells were split into 12-well plates and treated with a mixture of recombinant BMP2 and BMP7 adenoviruses to induce their osteoblast differentiation. Alkaline phosphatase activity was analyzed in cell lysates spectrophotometrically. Optical density at $405 \mathrm{~nm}$ is shown. Statistical differences are indicated $(*-P<0.05, * *-P<0.01)$. 
The intensive osteogenic processes in C2C12 and KS483 cells with stable expression of shRNAs target gene sequences specific for PTTG1 gene (anti-PTTG1_shRNA-1 and anti-PTTG1 shRNA-2) indicated PTTG1 as an important repressor of early stages of osteogenesis. In other our studies was demonstrated that shRNA-mediated knockdown of PTTG1 and PBF1 mRNAs expression also inhibited late stages of osteoblast differentiation during which Wnt signaling pathway is activated [22]. This showed that activation/inhibition and regulation of osteogenesis are poorly understood, in particular during RA pathogenesis. It is a complex system that includes many components and interactions and many of them are still unknown. Thus, our data together with results of other investigators allow us to hypothesize that PTTG1 and its partner protein PBF1 represents a novel key mechanism for regulation of the homeostasis of skeletal tissues. Our understanding of the precise molecular mechanisms and functional impact of inhibition of Wnt signaling pathway by PTTG1 is crucial for proper understanding of its role in bone remodelling and bone erosion formation during RA pathogenesis and progression. Besides this, understanding of these mechanisms can become a basis for development of novel strategies in diagnostics and treatment of this and other related disorders.

\section{Conclusions}

We found that shRNA-mediated knockdown of PTTG1 mRNA expression potentiated BMP-induced early stages of osteogenesis in stable multi-clonal cultures of $\mathrm{C} 2 \mathrm{C} 12$ and KS483 cell lines. The most pronounced effect was found for stably expressed anti-PTTG1_shRNA-1 which stimulated osteoblast differentiation in both $\mathrm{C} 2 \mathrm{C} 12$ and KS483 cells (2.1 and 2.7 fold, respectively), whereas anti-PTTG1_shRNA-3 stable expression did not show a significant effect on the osteoblast differentiation in these cells. Hence, PTTG1 is an important repressor of early stages of osteoblast differentiation and, thus, can serve as an inhibitor of bone remodelling, in particular, during RA progression.

Perspectives for future research. Next investigations will be focused at the validation of the biological significance of our results obtained in this study when using experimental model of mice with targeted inactivation of PTTG1 gene.

\section{Acknowlegments}

This work was partly supported by Young Scientist Carrier Support grant to C. M. from the West-Ukrainian BioMedical Research Centre (WUBMRC), and by the Molecular \& Cellular Biotechnologies Grant to O. K. from the National Academy of Sciences of Ukraine (Project no. 37).

1. Carreira A. C., Alves G. G., Zambuzzi W. F., Sogayar M. C., Granjeiro J. M. Bone Morphogenetic Proteins: structure, biological function and therapeutic applications. Archives of Biochemistry and Biophysics, 2014, 561, pp. 64-73.

2. Chen G., Deng C., Li Y. P. TGF- $\beta$ and BMP signaling in osteoblast differentiation and bone formation. International Journal of Biological Sciences, 2012, 8 (2), pp. 272-288.

3. Chen H., Senda T., Kubo K. Y. The osteocyte plays multiple roles in bone remodeling and mineral homeostasis. Medical Molecular Morphology, 2015, 48 (2), pp. 61-68.

4. Chien W., Pei L. A novel binding factor facilitates nuclear translocation and transcriptional activation function of the pituitary tumor-transforming gene product. Journal of Biological Chemistry, 2000, 275 (25), pp. 19422-19427.

5. Choy E. Understanding the dynamics: pathways involved in the pathogenesis of rheumatoid arthritis. Rheumatology, Oxford, 2012, 51, suppl. 5, pp. 3-11.

6. Diarra D., Stolina M., Polzer K., Zwerina J., Ominsky M. S., Dwyer D., Korb A., Smolen J., Hoffmann M., Scheinecker C., van der Heide D., Landewe R., Lacey D., Richards W. G., Schett G. Dickkopf-1 is a master regulator of joint remodeling. Nature Medicine, 2007, 13 (2), pp. 56-63.

7. Fire A., Xu S., Montgomery M. K., Kostas S. A., Driver S. E., Mello C. C. Potent and specific genetic interference by double-stranded RNA in Caenorhabditis elegans. Nature, 1998, 391, pp. 806-811.

8. Fujii M., Takeda K., Imamura T., Aoki H., Sampath T. K., Enomoto S., Kawabata M., Kato M., Ichijo H., Miyazono K. Roles of bone morphogenetic protein type I receptors and Smad proteins in osteoblast and chondroblast differentiation. Molecular Biology of the Cell, 1999, 10 (11), pp. 3801-3813.

9. Gabriel S. E. The epidemiology of rheumatoid arthritis. Rheumatic Disease Clinics of North America, 2001, 27 (2), pp. 269-281.

10. Galli C., Piemontese M., Lumetti S., Manfredi E., Macaluso G. M., Passeri G. The importance of Wnt pathways for bone metabolism and their regulation by implant topography. European Cells \& Materials, 2012, 24, pp. 46-59. 
11. Golub E. E., Boesze-Batt K. The role of alkaline phosphatase in mineralization. Current Opinion in Orthopaedics, 2007, 8, pp. 444-448.

12. Hashizume M., Mihara M. The roles of interleukin-6 in the pathogenesis of rheumatoid arthritis. Arthritis, 2011, 2011, 765624.

13. Imai K., Chiba T., Maeda G., Morikawa M. The role of Wnt in rheumatoid arthritis and its therapeutic implication. Mini-Reviews in Medicinal Chemistry, 2009, 9 (3), pp. 318-323.

14. Issack P. S., Heflet D. L., Lane J. M. Role of Wnt signaling in bone remodeling and repair. HSS Journal, 2008, 4 (1), pp. 66-70.

15. Johnson M. L., Kamel M. A. The Wnt signaling pathway and bone metabolism. Current Opinion in Rheumatology, 2007, 19 (4), pp. 376-382.

16. Jung S. M., Kim K. W., Yang C. W., Park S. H., $\mathrm{Ju}$ J. H. Cytokine-mediated bone destruction in rheumatoid arthritis. Journal of Immunology Research, 2014, 2014, pp. 263625.

17. Katagiri T., Yamaguchi A., Komaki M., Abe E., Takahashi N., Ikeda T., Rosen V., Wozney J. M., Fujisawa-Sehara A., Suda T. Bone morphogenetic protein-2 converts the differentiation pathway of $\mathrm{C} 2 \mathrm{C} 12$ myoblasts into the osteoblast lineage. The Journal of Cell Biology, 1994, 127 (6 pt 1), pp. 1755-1766.

18. Korchynskyi O. Adenoviral vectors: convenient tools for gene delivery to primary mammalian cells. Biotechnol Acta, 2012, 5 (5), pp. 16-26.

19. Korchynskyi O., Dechering K. J., Sijbers A. M., Olijve W., ten Dijke P. Gene array analysis of bone morphogenetic protein type I receptor-induced osteoblast differentiation. Journal of Bone and Mineral Research, 2003, 18 (7), pp. 1177-1185.

20. Korchynskyi O., Rutger L. van Bezooijen, Löwik C. W. G. M., ten Dijke P. Bone morphogenetic protein receptors and their nuclear effectors in bone formation. Bone Morphogenetic Proteins: From Discovery to Clinical Applications, Switzerland, Birkhauser Verlag, Basel, 2002, pp. 9-44.

21. Krishnan V., Bryant H. U., MacDougald O. A. Regulation of bone mass by Wnt signaling. Journal of Clinical Investigation, 2006, 116 (5), pp. 1202-1209.

22. Krupak V. I., Malysheva Kh. V., Pavlenko O. K., Shafranska G. I., de Rooij K., Löwik C. W. G. M., Stoika R. S., Korchynskyi O. G. The PTTG1 is a novel inhibitor of osteogenic differentiation of mouse mesenchymal stem cells. The Animal Biology, 2016, vol. 18, no. 1, pp. 61-68.

23. Kwan Tat S., Padrines M., Théoleyre S., Heymann D., Fortun Y. IL-6, RANKL, TNF-alpha/IL-1: interrelations in bone resorption pathophysiology, bone signaling pathways and treatment of osteoporosis. Cytokine \& Growth Factor Reviews, 2004, 15 (1), pp. 49-60.

24. Lequerré T., Bansard C., Vittecoq O., Derambure C., Hiron M., Daveau M., Tron F., Ayral X., Biga N., Auquit-Auckbur I., Chiocchia G., Le Loët X., Salier J. P. Early and long-standing rheumatoid ar- thritis: distinct molecular signatures identified by gene-expression profiling in synovia. Arthritis Research \& Therapy, 2009, 11 (3), pp. R99.

25. Logan C. Y., Nusse R. The Wnt signaling pathway in development and disease. Annual Review of Cell and Developmental Biology, 2004, 20, pp. 781-810.

26. MacDonald B. T., Tamai K., He X. Wnt/ $\beta$ catenin signaling: components, mechanisms, and disease. Developmantal Cell, 2009, 17 (1), pp. 9-26.

27. McInnes I. B., Schett G. The pathogenesis of rheumatoid arthritis. The New England Journal of Medicine, 2011, 365 (23), pp. 2205-2219.

28. Molina-Jiménez F., Benedicto I., Murata M., Martín-Vílchez S., Seki T., Antonio Pintor-Toro J., Tortolero M., Moreno-Otero R., Okazaki K., Koike K., Barbero J. L., Matsuzaki K., Majano P. L., López-Cabrera $\mathrm{M}$. Expression of pituitary tumor-transforming gene 1 (PTTG1)/securin in hepatitis B virus (HBV)associated liver diseases: evidence for an HBV X protein-mediated inhibition of PTTG1 ubiquitination and degradation. Hepatology, 2010, 51 (3), pp. 777-787.

29. Moore C. B., Guthrie E. H., Huang M. T., Taxman D. J. Short Hairpin RNA (shRNA): Design, Delivery, and Assessment of Gene Knockdown. Methods in Molecular Biology, 2010, 629, pp. 141-158.

30. Park J. Y., Pillinger M. H. Interleukin-6 in the pathogenesis of rheumatoid arthritis. Bulletin of the NYU Hospital for Joint Diseases, 2007, 65, suppl. 1, pp. 4-10.

31. Pederson L., Ruan M., Westendorf J. J., Khosla S., Oursler M. J. Regulation of bone formation by osteoclasts involves Wnt/BMP signaling and the chemokine sphingosine-1-phosphate. Proceedings of the National Academy of Sciences of the United States of America, 2008, 105 (52), pp. 20764-20769.

32. Pei L. Activation of mitogen-activated protein kinase cascade regulates pituitary tumor-transforming gene transactivation function. Journal of Biological Chemistry, 2000, 275 (40), pp. 31191-31198.

33. Pei L., Melmed S. Isolation and characterization of a pituitary tumor-transforming gene (PTTG). Moelcular Endocrinology, 1997, 11 (4), pp. 433-441.

34. Prezant T. R., Kadioglu P., Melmed S. An intronless homolog of human proto-oncogene hPTTG is expressed in pituitary tumors: evidence for $\mathrm{hPTTG}$ family. Journal of Clinical Endocrinology and Metabolism, 1999, 84 (3), pp. 1149-1152.

35. Rabelo Fde S., da Mota L. M., Lima R. A., Lima F. A., Barra G. B., de Carvalho J. F, Amato A. A. The Wnt signaling pathway and rheumatoid arthritis. Autoimmunity Reviews, 2010, 9 (4), pp. 207-210.

36. Rawadi G., Roman-Roman S. Wnt signalling pathway: a new target for the treatment of osteoporosis. Expert Opinion on Therapeutic Targets, 2005, 9 (5), pp. 1063-1077.

37. Salehi F., Kovacs K., Scheithauer B. W., Lloyd R. V., Cusimano M. Pituitary tumor-transforming gene in endocrine and other neoplasms: a review 
and update. Endocrine-Related Cancer, 2008, 15 (3), pp. 721-743.

38. Schett G., Gravallese E. Bone erosion in rheumatoid arthritis: mechanisms, diagnosis and treatment. Nature Reviews Rheumatology, 2012, 8(11),pp. 656-664.

39. Smolen J. S., Aletaha D., Koeller M., Weisman M. H., Emery P. New therapies for treatment of rheumatoid arthritis. Lancet, 2007, 370 (9602), pp. 1861-1874.

40. Stock M., Schäfer H., Fliegauf M., Otto F. Identifcation of Novel Target Genes of the Bone Specifc Transcription Factor Runx2. Journal of Bone and Mineral Research, 2004, 19 (6), pp. 959-972.

41. Tfelt-Hansen J., Kanuparthi D., Chattopadhyay N. The emerging role of pituitary tumor transforminggene in tumorigenesis. Clinical Medicine \& Research, 2006, 4 (2), pp. 130-137.

42. Van der Horst G., van Bezooijen R. L., Deckers M. M., Hoogendam J.,Visser A., Löwik C. W., Karperien M. Differentiation of murine preosteoblastic KS483 cells depends on autocrine bone morpho- genetic protein signalling during all phases of osteoblast formation. Bone, 2002, 31 (6), pp. 661-669.

43. Wang Z., Yu R., Melmed S. Mice lacking pituitary tumor transforming gene show testicular and splenic hypoplasia, thymic hyperplasia, thrombocytopenia, aberrant cell cycle progression, and premature centromere division. Molecular Endocrinology, 2001, 15 (11), pp. 1870-1879.

44. Yu R., Cruz-Soto M., Li C. S., Hui H., Melmed S. Murine pituitary tumor-transforming gene functions as a securin protein in insulin-secreting cells. Journal of Endocrinology, 2006, 191 (1), pp. 45-53.

45. Zhang X., Horwitz G. A., Prezant T. R., Valentini A., Nakashima M., Bronstein M. D., Melmed S. Structure, expression, and function of human pituitary tumor-transforming gene (PTTG). Molecular Endocrinology, 1999, 13 (1), pp. 156-166.

46. Zou H., McGarry T.J., Bernal T., Kirschner M.W. Identifcation of a vertebrate sister-chromatid separation inhibitor involved in transformation and tumorigenesis. Science, 1999, 285 (5426), pp. 418-422. 